\title{
WPŁYW POZIOMU WOLNOŚCI NA STOPIEŃ ZAWODNOŚCI RYNKU W WYBRANYCH KRAJACH ŚWIATA - PROBLEM UBÓSTWA
}

\author{
Ciekawośc to delikatna roślinka, która, niezależnie \\ od pobudzania, potrzebuje przede wszystkim wolnosici.
}

Albert Einstein

\section{WSTĘP}

Podczas długiego okresu kształtowania się teorii ekonomii wiele razy doświadczano sytuacji, gdy skuteczna interwencja rządu przynosiła poprawę na lepsze. Rynek pozostawiony niewidzialnej ręce często zawodził. Otwartą kwestią, także w kontekście obecnego kryzysu, pozostaje pytanie o właściwą równowagę pomiędzy wolnością a interwencjonizmem i poziomem regulacji. Według noblisty z dziedziny ekonomii J. E. Stiglitza rynek nie jest celem samym w sobie, powinien służyć do osiągania celów, takich jak poprawa poziomu życia. Wyznaje on także pogląd, że demokracja i poziom wolności stanowią istotne elementy przyczyniające się do poprawy jakości życia, wydajności danej gospodarki. Celem niniejszej pracy jest próba znalezienia powiązań między wolnością polityczną oraz wolnością swobód obywatelskich w kraju a jego efektywnością mierzoną skalą występującego w nim ubóstwa (mierzonego jego zasięgiem, głębokością oraz współczynnikiem Giniego) - czynnika wymienianego przez wielu ekonomistów jako jedna z podstawowych zawodności rynku.

\section{KRÓTKIE PRZYBLIŻENIE POJĘCIA WOLNOŚCI}

Wolność jest pojęciem abstrakcyjnym i trudnym do zdefiniowania w kilku słowach. Znaczenie tego terminu zmieniało się na przestrzeni wieków. Współ- 
cześnie rozumiemy to pojęcie inaczej niż przedstawiciele wielkiej filozofii. Platon twierdził, że wolność jest dobrem, w którym dusza chce uczestniczyć w celu samodoskonalenia się. U Arystotelesa do wolności potrzebny jest akt woli oraz pewna szczególna zdolność do podejmowania decyzji. Filozofią wolności zajmował się także Kartezjusz z jego indeterministyczną wersją, a także wielu innych, jak: Spinoza, Marks czy Hegel ${ }^{1}$. Jednak nawet dziś H. Arendt twierdzi, że uchwycenie istoty wolności jest „równie niemożliwe jak zrozumienie kwadratury koła”2. Mimo tego, pojęcie wolności większość rozumie intuicyjnie. Jest to pewna powszechnie akceptowana wartość. Wyraża się ona jako prawo dokonywania wyboru pomiędzy określonymi możliwościami. Wybór ten nie jest jednak wymuszony przez jakiekolwiek czynniki działające poza świadomością człowieka ${ }^{3}$. Generalnie uważa się, że obecność wolności oraz jej powiększanie są lepsze niż jej brak lub zawężanie. Wolność można zdefiniować także jako stan egzystencji pewnego zakresu spraw wolnego od zewnętrznej ingerencji. Taka definicja nie jest jednak wystarczająca. Dlatego istotne jest poświęcenie większej uwagi temu pojęciu. Wolność należy rozpatrywać indywidualnie. Nie należy przyglądać się jej kolektywnie ${ }^{4}$. Wolny naród nie może być traktowany jako prawdziwie wolny, jeżeli jego pojedynczy obywatele nie są ludźmi wolnymi. Ważny jest także fakt, że wolność dotyczy tak naprawdę stosunków międzyludzkich. Nie należy rozpatrywać wolności w stosunku do relacji ludzi do rzeczy, tak jak to czynili marksiści ${ }^{5}$. Prowadziło to do definiowania wolności w relacji do posiadanych dóbr. Poprzez przedstawianie problemu biedy łatwo można było uzyskać błędny wniosek, że właściwie wolność nie istnieje. Poglądy takie analizuje na przykład Ludwig von Mises w pracy Liberty and Property (Auburn, Alabama 1988). Co więcej, skoro bieda istnieje w warunkach wolności, zatem to wolność jest odpowiedzialna za owy stan rzeczy, z których i tak korzystają tylko wybrani, czyli bogaci kapitaliści. Tam, gdzie zawierzono owym ideom, zginęła nie tylko wolność, ale i utrwaliło się zacofanie. Oprócz zrozumienia idei wartości bardzo ważną kwestią jest szukanie odpowiedzi na pytanie o poziom pożądanej wolności. Jest to istotne w dzisiejszych czasach, także w krajach najwyżej rozwiniętych i demokratycznych. Pytania o poziom wolności, jakim powinien charakteryzować się wolny rynek, nadal szukają odpowiedzi. W kontekście kryzysu na amerykańskim rynku subprime nasiliły się wątpliwości co do poziomu wolności oraz potrzeby odpowiednich regulacji na rynku usług finansowych.

\footnotetext{
${ }^{1}$ Por. W. Tatarkiewicz, Historia filozofii, Wydawnictwo Naukowe PWN, Warszawa 2007.

${ }^{2}$ H. Arendt, Co to jest wolnosic?, Warszawa 1994, s. 176.

${ }^{3}$ B. Pogonowska, W. Kot, H. Zboroń (red.), Elementy etyki rynkowej, Polskie Wydawnictwo Ekonomiczne, Warszawa 2000, s. 242.

${ }^{4}$ I. Berlin, Dwie koncepcje wolności, [w:] idem, Cztery eseje o wolności, Warszawa 1991.

${ }^{5}$ L. Balcerowicz, Wolność i rozwój. Ekonomia wolnego rynku, Wydawnictwo Znak, Kraków 1998, s. 10.
} 
Rozpatrując pożądany poziom wolności, należy ustalić zarówno jej kres dolny, jak i górny. Gdy wolność spada poniżej pewnego krytycznego poziomu, mówi się wówczas o jej braku lub w przypadku wolności osobistej o niewoli. Podczas szukania kresu górnego nie można zgodzić się z poglądem, jakoby w każdym przypadku więcej wolności znaczyło lepiej. Sidney Hook, wybitny amerykański filozof, wskazuje żartobliwie, że ideał wolności badań naukowych nie obejmuje wiwisekcji na ludziach ${ }^{6}$. Wolność maksymalnie szeroka oznaczałaby zgodę na zachowania, które wyrządzałyby krzywdę innym ludziom, na zachowania społecznie nieakceptowane. W przypadku omawiania optymalnego zakresu wolności gospodarczej również nie może być zgody na maksymalnie szeroki poziom wolności. Podmioty gospodarcze muszą przestrzegać prawa, w tym prawa pracy, nie może być także zgody na niczym nieograniczone szkody wyrządzane środowisku. $Z$ wolnością powiązana jest filozofia liberalizmu. Według niej kryterium granicy maksymalnej wolności jest respekt dla innych ludzi ${ }^{7}$. Można to sparafrazować słowami, że tam kończy się wolność człowieka, gdzie zaczyna się wolność innych ludzi. Państwo w tej koncepcji powinno stać na straży indywidualnej wolności. Aparat przymusu jest aprobowany, ale tylko w celu ochrony wolności przed naruszeniem ze strony innych ludzi. Zabezpieczeniem przed różnymi formami ograniczeń, jak najrozmaitsze przepisy, podatki, tak aby wolność utrzymywana była w pewnych ramach, jest odpowiednio ukształtowana konstytucja. Wolność w poszczególnych krajach jest sankcjonowana prawem lub panującym ustrojem gospodarczym. Jej wyznacznikiem są uprawnienia przysługujące określonym jednostkom. Wolność rozumiana jako brak przymusu według Miltona Friedmana jest najwyższą wartością․ To z pojęcia owej wolności wyłania się wolność ekonomiczna, która ma stanowić cel sam w sobie. Ludzie powodowani wzajemnie sprzecznymi interesami mają przyczyniać się dla dobra ogółu i własnego. Wolność, według M. Friedmana, wykracza poza dzisiejszy sposób pojmowania tego pojęcia. Każdy człowiek, zgodnie z powyższym rozumowaniem, powinien otrzymywać tyle, ile potrafi zarobić, a państwo powinno charakteryzować się niezbędnym minimalizmem ${ }^{9}$. Wolność musi mieć jednak swoje granice. Po ich przekroczeniu popada się nie w jeszcze wyższy poziom wolności, lecz w samowolę. Samowola w sferze działalności gospodarczej jest szkodliwa, ponieważ mechanizm regulujący rynek nie działa tak sprawnie, jak byśmy sobie tego życzyli ${ }^{10}$.

${ }^{6}$ S. Hook, Paradoxes of Freedom, New York 1987.

${ }^{7}$ I. Berlin, op. cit., s. 163.

${ }^{8}$ M. Friedman, Economic Libertarianism, [w:] M. D. Ketchuma, N. Strunka (red.), Conference on Savings and Residential Financing Proceedings, Chicago 1965, s. 20.

${ }^{9}$ Ibidem, s. 162.

${ }^{10}$ J. Filek, Etyka w dziatalności gospodarczej, [w:] W. Gasparski, A. Lewicka-Strzałecka, D. Miller (red.), Etyka biznesu gospodarki i zarządzania, Wydawnictwo Wyższej Szkoły Humanistyczno-Ekonomicznej w Łodzi, Warszawa 1999. 
Istnieje wiele rodzajów wolności, które wzajemnie się przenikają i uzupełniają. Podstawową kategorią wolności jest wolność osobista. Bez wolności osobistej w sposób oczywisty nie mogą istnieć pozostałe rodzaje wolności. Rozróżnić należy także wolność gospodarczą. Obejmuje ona prawo do działalności zarobkowej, do prywatnej przedsiębiorczości, gwarantuje swobodę zawierania umów, wyboru zawodu, typu i miejsca pracy. Stanowi ona fundament rozwoju gospodarki oraz stałej poprawy warunków życia. Wolność gospodarcza skutkuje pojawieniem się konkurencji, która zmusza do innowacyjności i gospodarności. Wolność polityczna to równość wszystkich obywateli w zakresie posiadanych praw wyborczych. Wolność polityczna nie może jednak istnieć, jeżeli brakuje wolności słowa, swobody zrzeszania się czy swobody zakładania partii politycznych. Wolność można zatem utożsamiać z demokracją ${ }^{11}$. Milton Friedman wskazuje na wzajemną zależność wolności, wolnego rynku i przedsiębiorczości. Według niego, wolność polityczna bez wolnego rynku i prywatnej przedsiębiorczości jest trudna do utrzymania w dłuższym okresie ${ }^{12}$. Potwierdzeniem tych rozważań jest dotychczasowa historia gospodarcza. Mianowicie kraje o trwałej demokracji charakteryzowały się także dużym zakresem wolności obywatelskich. Wolność osobista, gospodarcza i polityczna wzajemnie się zazębiają, tworząc wartość, bez której nie następowałby dynamiczny rozwój i poprawa warunków życia, jaka obecnie ma miejsce w krajach rozwiniętych. Sam fakt istnienia wolności ekonomicznej nie jest niestety warunkiem wystarczającym prawidłowego funkcjonowania wolnego społeczeństwa. Dodatkowymi warunkami, które muszą być spełnione, to odpowiednie instytucje polityczne oraz pewien system wartości danego społeczeństwa ${ }^{13}$.

Opisując kwestie związane z wolnością, nie sposób nie odnieść się do siostrzanych pojęć równości i sprawiedliwości. Liberalny wzorzec łączy w sobie zarówno wolność, jak i równość. Wolność daje pewien określony zakres ogólnych swobód, natomiast równość gwarantuje możliwość korzystania $\mathrm{z}$ owych swobód przez wszystkich obywateli z równym stopniem ochrony praw. Według L. Balcerowicza połączenie wolności oraz równości w zakresie szerokiego zestawu szans jest w stanie zapewnić szybszy rozwój niż w przypadku zawężonej w imię etatystycznych wizji państwa wolności gospodarczej ${ }^{14}$. Brak równości we władzy prowadzi do uprzywilejowywania pewnych grup, które mogą czerpać z tego tytułu rozmaite korzyści. Naturalnym rezultatem braku równości we władzy będzie zatem nierówność zakresów wolności. Można to traktować jako jedno z wytłumaczeń, dlaczego kraje Ameryki Łacińskiej uprawiające etatystyczny interwencjonizm

${ }^{11}$ L. Balcerowicz, op. cit., s. 17.

${ }^{12}$ M. Friedman, Kapitalizm i wolność, Warszawa 1993.

${ }^{13}$ Idem, Capitalism and Freedom, [w:] F. Morley (red.), Essays on Individuality, University of Pennsylvania Press, Philadelphia 1958, s. 168-182.

${ }^{14}$ L. Balcerowicz, op. cit., s. 16. 
charakteryzowały się dużo większymi nierównościami i słabszym rozwojem niż „azjatyckie tygrysy" ${ }^{15}$. Ponadto wolność indywidualna, w przeciwieństwie do kolektywnej, nie może istnieć, gdy występuje deficyt równości wszystkich obywateli. Pojęcie sprawiedliwości jest pojęciem szerszym od pojęcia równości. Sprawiedliwość jest pojęciem względnym i nieraz często trudno jest określić, gdzie zaczyna, a gdzie kończy się sprawiedliwość. Należy jednak stwierdzić, że bez elementarnego poziomu sprawiedliwości funkcjonowanie wolności i równości w społeczeństwie byłoby poważnie zakłócone.

Z poglądem tym zgadza się laureat Nagrody Nobla Joseph Stiglitz. Twierdzi on, że wolność, równość i sprawiedliwość to kamienie węgielne kierunków pożądanego rozwoju ${ }^{16}$. Wolność ma bowiem wpływ na politykę gospodarczą i społeczną, poprzez co wpływa na warunki prowadzenia działalności gospodarczej, na naukę, innowacyjność, mentalność, poziom kulturalny, a więc wolność wpływa poprzez wszystkie wymienione czynniki pośrednio także na postęp techniczny. Postęp techniczny jest natomiast niezbędny dla podnoszenia ogólnego dobrobytu i zapewniania coraz sprawniej działającego państwa i rynku. Podobnego zdania jest wielu innych ekonomistów, jak np. J. C. Kim, twierdzący, że zwiększona wolność gospodarcza jest w stanie zwiększyć gospodarcze sukcesy kraju - także w odniesieniu do najbiedniejszych krajów Afryki ${ }^{17}$.

\section{WOLNOŚĆ A UBÓSTWO}

Zdefiniowanie konkretnych charakterystyk pojęcia ubóstwo nastręcza trudności. W literaturze występuje wiele definicji, a przyjęcie kryterium wyznaczników ubóstwa ma kluczowe znaczenie dla kwestii wdrażania programów do jego zwalczania, a przede wszystkim do znalezienia właściwej grupy osób nim zagrożonych $^{18}$. Powszechna zgoda dotyczy tego, że ubóstwo to stan niezaspokojenia pewnych potrzeb na określonym poziomie ${ }^{19}$. Współcześnie za podstawowe potrzeby uznaje się nie tylko żywność, mieszkanie i odzież, ale zakres podstawowych po-

${ }^{15}$ Por. The East Asian Miracle, „Economic Growth and Public Policy”, A World Bank Policy Report, Washington.

${ }^{16}$ J. E. Stiglitz, Szalone lata dziewięćdziesiate, Wydawnictwo Naukowe PWN, Warszawa 2006, s. 255.

${ }_{17}^{17}$ J. C. Kim, Economic Freedom and the African Growth and Opportunity Act, July 15, 2008, Heritage Foundation: http://www.heritage.org lub http://www.freedomhouse.org/template. cfm?page=351\&ana_page=333\&year=2007.

${ }_{18}$ Por. np. G. Carbonaro, Major Problems in the Measurement of Poverty, an Overview, [w:] Poverty Measurement for Economies in Transition in Eastern European Countries, Polish Statistical Association, Warsaw 1992, s. 15-42.

${ }^{19}$ J. Drewnowski, Poverty: It's Meaning and Measurement, „Development and Change” 1997, no. 8 , s. $183-208$. 
trzeb został rozszerzony w kierunku możliwości uczestniczenia w życiu społecznym i kulturalnym. Ubóstwo według A. Sena to brak wystarczających dochodów połączony z brakiem możliwości zaspokojenia podstawowych potrzeb na danym etapie rozwoju społecznego ${ }^{20}$. Podczas światowego szczytu w Kopenhadze rekomendowano dwupoziomową miarę ubóstwa ${ }^{21}$. Zgodnie z przyjętą metodologią rozróżniono ubóstwo absolutne i ogólne. Definicja ubóstwa absolutnego obejmowała niemożność zaspokojenia takich podstawowych potrzeb, jak: żywność, woda pitna, urządzenia sanitarne, zdrowie, mieszkanie i informacja. Ubóstwo zgodnie $\mathrm{z}$ tą definicją zależy nie tylko od dochodów, ale także od dostępu do pewnych usług. Ubóstwo ogólne, będące kategorią jeszcze szerszą, zawiera brak możliwości uczestnictwa w podejmowaniu decyzji, w życiu obywatelskim, społecznym i kulturalnym. Dla potrzeb niniejszej pracy i zapewnienia porównywalności międzynarodowej przyjęto powszechną i najprostszą definicję ubóstwa ekonomicznego. Ubóstwo ekonomiczne to sytuacja, gdy jednostka nie posiada wystarczających środków pieniężnych do zaspokojenia swoich podstawowych potrzeb.

Powszechnie wiadomo, że rynki nie działają sprawnie. Występuje wiele dysfunkcji i zawodności. Zawodności, które nie mogą zostać wyeliminowane samoistnie, wymagają aktywnej interwencji. Najczęściej uważa się, że do takiej interwencji upoważnione jest państwo. Państwo ma jednak ograniczone możliwości działania. Wszelkie zasoby są bowiem zawsze ograniczone w stosunku do nieograniczonych potrzeb. Państwo także nie jest pozbawione tej ułomności. Interwencje państwa są zatem dokonywane $\mathrm{w}$ takich granicach, na jakie może sobie ono pozwolić. Poziom wolności indywidualnych jednostek może mieć decydujący wpływ na wielkość występujących zawodności. Wolność działa bowiem jako mechanizm zachęcający oraz z drugiej strony dyscyplinujący obywateli i co za tym idzie może wpływać na jakość funkcjonowania państwa. Państwa socjalistyczne z bardzo nikłym polem wolności jednostki charakteryzowały się większym marnotrawstwem zasobów i mniejszą efektywnością. Kwestią otwartą pozostaje, czy w państwach demokratycznych zależność między wolnością jednostki a efektywnością nadal istnieje. John Locke uważał, że jednym z warunków sprawnego funkcjonowania demokracji jest prawo do wypowiadania własnego zdania i zrzeszania się. Prawo swobody wypowiedzi i zrzeszania się składa się na wolność polityczną jednostki. Bez niej nie byłoby możliwe prowadzenie uczciwych dysput politycznych oraz forsowania własnych poglądów w ramach wspólnoty ${ }^{22}$. Wolność polityczna jest

${ }^{20}$ A. Sen, Poverty: An Ordinal Approach to Measurement, „Econometrica” 1976, vol. 44, s. 219-231.

${ }^{21}$ United Nations UN, The Copenhagen Declaration and Programme of Action: World Summit for Social Development, G-12 March 1995, United Nations Department of Publications, New York 1995.

${ }^{22} \mathrm{~J}$. Locke, Essays on the law of nature, Oxford 1676. 
natomiast silnie związana $z$ wolnością ekonomiczną. Wolności polityczna i ekonomiczna składają się na szeroko rozumianą wolność, mogącą mieć potencjalny wpływ na zawodności rynku.

Do zawodności rynków należy zaliczyć według większości ekonomistów ubóstwo i bardzo blisko powiązane z nim bezrobocie. Joseph E. Stiglitz twierdzi, że bezrobocie jest najbardziej dramatycznym defektem rynku, ponieważ oznacza ono marnotrawienie cennego zasobu. Dlatego państwo, nawet kosztem walki z inflacją, powinno starać się zapewnić stan jak najbliższy stanowi pełnego zatrudnienia ${ }^{23}$. Większa wolność powinna sprzyjać bardziej demokratycznym rządom i przekładać się w długim okresie na zmniejszenie defektu pozostawania ludzi bez pracy. Większe zatrudnienie to większa szansa na uniknięcie problemu ubóstwa. Wszyscy zyskują w społeczeństwie, gdzie ubóstwo i nierówności są mniejsze. Dowodem mogą być te kraje Azji Wschodniej, które ograniczyły nierówności i doświadczyły szybszego rozwoju. Przyczyną takiego stanu rzeczy może być lepszy sposób wykorzystania potencjału ludzkiego oraz większa stabilność społeczna i polityczna. Zwiększona wolność niesie ze sobą ryzyko powstania pewnych grup społecznych, które mogą znaleźć się bez minimalnych środków do życia. Do rozwiązania tego problemu, dotyczącego wszystkich krajów świata, potrzebne są programy walki z ubóstwem. Ograniczoność środków na ten cel powoduje, że wyeliminowanie ubóstwa staje się rzeczą niesłychanie trudną. Państwa o bardziej zakorzenionej wolności i osiągające przez to lepsze wyniki gospodarcze powinny, przynajmniej w teorii, mieć lepsze rezultaty w zwalczaniu tego defektu rynku.

\section{EMPIRYCZNA ANALIZA ZALEŻNOŚCI WOLNOŚCI I UBÓSTWA}

Za ubogie uznano w niniejszej pracy osoby żyjące w 87 krajach świata za mniej niż 2 dolary dziennie, mierzone parytetem siły nabywczej z 2005 roku. Do badań wykorzystano głównie trzy miary ubóstwa mierzące jego zasięg, głębokość oraz społeczny rozkład dochodów. Podstawową miarą oceniającą zasięg ubóstwa i wykorzystaną w pracy jest stopa ubóstwa. Jest to odsetek gospodarstw domowych znajdujących się poniżej granicy ubóstwa. W badaniach ubóstwa istotne znaczenie ma także odpowiedź na pytanie, jak daleko znajdują się one od granicy ubóstwa (\%). Podstawową miarą oceniającą ową głębokość ubóstwa jest indeks luki dochodowej ubogich. Jeżeli przykładowo wynosi on 10\%, oznacza to, że przeciętna zamożność gospodarstw ubogich jest o 10\% mniejsza od granicy ubóstwa. Istotne jest także dokonywanie pomiaru ubóstwa względnego, czyli w odniesieniu do innych gospodarstw domowych. Najczęściej do analiz nierówności wykorzystuje się

\footnotetext{
${ }^{23}$ J. E. Stiglitz, op. cit., s. 253.
} 
wskaźnik Giniego. Współczynnik przyjmuje wartości od 0 do 1 . Wartość 0 oznacza równomierność rozkładu rozporządzalnych dochodów. Wartość 1 oznacza, że jedno gospodarstwo posiada cały dochód ${ }^{24}$. Pozostałe wskaźniki przedstawione w załączniku to wskaźnik dotkliwości ubóstwa (SPG), będący kwadratem wskaźnika luki dochodowej, indeks Watta, który posiada wiele właściwości przydatnych do matematycznych modyfikacji i porównań, oraz indeks MLD 25 .

Pomiar wolności został dokonany na dwóch płaszczyznach: wolności politycznej (political liberties) i wolności swobód obywatelskich (civil liberties). Każdy kraj otrzymuje wskaźnik w skali od 1 do 7 dla każdego rodzaju wolności. Wartość 1 oznacza najwyższy współczynnik wolności, natomiast wartość 7 najmniejszą ilość wolności ${ }^{26}$.

Do badań wykorzystano dane za lata 2003-2007, aby w miarę możliwości zachować spójność czasową porównywanych danych. Wszelkie wskaźniki ubóstwa są obliczone ze względu na ankiety przeprowadzane przez Bank Światowy, stąd $\mathrm{w}$ tabeli lata reprezentujące okres, w którym ankieta miała miejsce. Odpowiednio do tego okresu przyznawano w tabeli wolność polityczną i wolność swobód obywatelskich, jaka istniała w tym samym okresie. Badaniem zostały objęte wszystkie kraje w liczbie 87, dla których Bank Światowy udostępnił szczegółowe dane dotyczące ubóstwa.

Tabela 1. Wskaźniki wolności i ubóstwa dla poszczególnych krajów mierzone parytetem siły nabywczej z 2005 roku

\begin{tabular}{|l|c|c|c|c|c|c|}
\hline & RoK ANKIETY & $\begin{array}{c}\text { WoLNOŚĆ } \\
\text { POLITYCZNA }\end{array}$ & $\begin{array}{c}\text { WOLNOŚĆ } \\
\text { SWOBÓD } \\
\text { OBYWATELSKICH }\end{array}$ & $\begin{array}{c}\text { ZASIĘG } \\
\text { UBÓSTWA (\%) }\end{array}$ & $\begin{array}{c}\text { GŁĘBOKOŚĆ } \\
\text { UBÓSTWA (\%) }\end{array}$ & $\begin{array}{c}\text { WSKAŹNIK } \\
\text { GINIEGO }\end{array}$ \\
\hline Albania & 2005 & 3 & 3 & 7,94 & 1,46 & 33,03 \\
\hline Angola & 2000 & 6 & 6 & 70,3 & 42,42 & 58,64 \\
\hline Argentina & 2005 & 2 & 2 & 11,35 & 3,61 & 50,03 \\
\hline Armenia & 2003 & 4 & 4 & 43,68 & 11,36 & 33,8 \\
\hline Azerbejdżan & 2005 & 6 & 5 & 0,28 & 0,04 & 16,83 \\
\hline Bangladesz & 2005 & 4 & 4 & 80,44 & 34,47 & 33,22 \\
\hline Białoruś & 2005 & 7 & 6 & 0,49 & 0,2 & 27,92 \\
\hline
\end{tabular}

${ }^{24}$ Bank Światowy, http://www.worldbank.org, oraz T. Panek, Ubóstwo i nierówności: dylematypomiaru, [w:] T. Panek (red.), Statystyka spoteczna, Polskie Wydawnictwo Ekonomiczne, Warszawa 2007.

${ }^{25}$ Por. C. Muller, The Properties of the Watts Poverty Index, September 1998.

${ }^{26}$ Całkowita metodologia przyznawania ratingów wolności dostępna jest na stronie Freedom House: http://www.freedomhouse.org, lub na stronie http://www.freedomhouse.org/template. cfm?page=351\&ana_page=333\&year=2007. 
Tabela 1. Wskaźniki wolności i ubóstwa (ciąg dalszy)

\begin{tabular}{|c|c|c|c|c|c|c|}
\hline & RoK ANKIETY & $\begin{array}{l}\text { WOLNOŚĆ } \\
\text { POLITYCZNA }\end{array}$ & $\begin{array}{c}\text { WOLNOŚĆ } \\
\text { SWOBÓD } \\
\text { OBYWATELSKICH }\end{array}$ & $\begin{array}{c}\text { ZASIEEG } \\
\text { UBóSTWA (\%) }\end{array}$ & $\begin{array}{c}\text { GŁĘBOKOŚĆ } \\
\text { UBÓSTWA (\%) }\end{array}$ & $\begin{array}{l}\text { WSKAŻNIK } \\
\text { GINIEGO }\end{array}$ \\
\hline Benin & 2003 & 3 & 2 & 75,46 & 33,62 & 38,62 \\
\hline Bhutan & 2003 & 6 & 5 & 49,66 & 18,92 & 46,83 \\
\hline Boliwia & 2005 & 3 & 3 & 30,43 & 15,52 & 58,19 \\
\hline $\begin{array}{l}\text { Bośnia i Herce- } \\
\text { gowina }\end{array}$ & 2004 & 4 & 4 & 0,69 & 0,18 & 35,78 \\
\hline Brazylia & 2005 & 2 & 3 & 18,41 & 5,96 & 56,39 \\
\hline Bułgaria & 2003 & 1 & 2 & 2,37 & 0,86 & 29,24 \\
\hline Burkina Faso & 2003 & 4 & 4 & 81,32 & 39,37 & 39,6 \\
\hline Burundi & 2006 & 3 & 5 & 93,49 & 56,16 & 33,27 \\
\hline Kambodża & 2004 & 6 & 5 & 68,34 & 28,11 & 41,85 \\
\hline $\begin{array}{l}\text { Central African } \\
\text { Rep. } \\
\end{array}$ & 2003 & 5 & 5 & 81,99 & 45,4 & 43,57 \\
\hline Czad & 2002.5 & 6 & 5 & 83,37 & 44,03 & 39,78 \\
\hline Chile & 2006 & 1 & 1 & 2,41 & 0,4 & 52 \\
\hline Chiny rural & 2005 & 7 & 6 & 55,81 & 19,57 & 35,85 \\
\hline Chiny urban & 2005 & 7 & 6 & 9,46 & 2,14 & 34,8 \\
\hline Kolumbia & 2006 & 4 & 4 & 27,96 & 11,92 & 58,49 \\
\hline $\begin{array}{l}\text { Kolumbia } \\
\text { urban }\end{array}$ & 1991 & 4 & 4 & 17,51 & 6,48 & 51,32 \\
\hline $\begin{array}{l}\text { Dem. Rep. } \\
\text { Kongo }\end{array}$ & 2005.5 & 6 & 6 & 79,65 & 42,49 & 44,43 \\
\hline Kostaryka & 2005 & 1 & 1 & 8,61 & 2,32 & 47,23 \\
\hline Chorwacja & 2005 & 2 & 2 & 0 & 0 & 28,99 \\
\hline Dżibutti & 2002 & 5 & 4 & 41,35 & 14,66 & 39,96 \\
\hline $\begin{array}{l}\text { Dominikan Re- } \\
\text { public }\end{array}$ & 2005 & 2 & 2 & 15,17 & 4,35 & 49,97 \\
\hline Ekwador & 2005 & 3 & 3 & 20,47 & 7,68 & 53,65 \\
\hline Egipt & 2004.5 & 6 & 5 & 18,64 & 3,5 & 32,14 \\
\hline El Salvador & 2005 & 2 & 3 & 20,55 & 8,9 & 49,7 \\
\hline Estonia & 2004 & 1 & 2 & 1,55 & 0,48 & 36 \\
\hline Etiopia & 2005 & 5 & 5 & 77,73 & 28,99 & 29,76 \\
\hline Gabon & 2005 & 5 & 4 & 19,71 & 5,06 & 41,45 \\
\hline Georgia & 2005 & 3 & 4 & 30,54 & 10,98 & 40,78 \\
\hline Ghana & 2005.5 & 2 & 2 & 53,77 & 22,4 & 42,76 \\
\hline Gwatemala & 2006 & 4 & 4 & 25,8 & 9,67 & 53,69 \\
\hline Gwinea & 2003 & 6 & 5 & 87,3 & 50,36 & 43,34 \\
\hline Honduras & 2005 & 3 & 3 & 34,85 & 16,78 & 56,71 \\
\hline Węgry & 2004 & 1 & 2 & 0 & 0 & 30,04 \\
\hline
\end{tabular}


Tabela 1. Wskaźniki wolności i ubóstwa (ciąg dalszy)

\begin{tabular}{|c|c|c|c|c|c|c|}
\hline & RoK ANKIETY & $\begin{array}{l}\text { WolNość } \\
\text { POLITYCZNA }\end{array}$ & $\begin{array}{c}\text { WOLNOŚĆ́ } \\
\text { SWOBÓD } \\
\text { OBYWATELSKICH }\end{array}$ & $\begin{array}{c}\text { ZASIEGG } \\
\text { UBÓSTWA (\%) }\end{array}$ & $\begin{array}{l}\text { GtęвокоŚĆ } \\
\text { UBÓSTwA (\%) }\end{array}$ & $\begin{array}{c}\text { WSKAŻNIK } \\
\text { GINIEGO }\end{array}$ \\
\hline Indie Rural & 2004.5 & 2 & 3 & 79,67 & 31,02 & 30,46 \\
\hline Indie urban & 2004.5 & 2 & 3 & 66 & 26,09 & 37,59 \\
\hline Indonezja & 2005 & 3 & 4 & 61,4 & 19,66 & 29,52 \\
\hline Iran & 2005 & 6 & 6 & 8,1 & 1,82 & 38,28 \\
\hline Jamajka & 2004 & 2 & 3 & 5,91 & 0,94 & 45,51 \\
\hline Jordan & 2006 & 5 & 4 & 3,51 & 0,62 & 37,72 \\
\hline Kazachstan & 2003 & 6 & 5 & 17,29 & 3,95 & 33,85 \\
\hline Kenia & 2005.4 & 3 & 3 & 40,05 & 15,18 & 47,68 \\
\hline Łotwa & 2004 & 1 & 2 & 1,05 & 0,36 & 35,73 \\
\hline Liberia & 2007 & 3 & 4 & 94,88 & 59,61 & 52,56 \\
\hline Litwa & 2004 & 1 & 2 & 1,57 & 0,46 & 35,81 \\
\hline Macedonia & 2003 & 3 & 3 & 3,2 & 0,65 & 38,95 \\
\hline Madagaskar & 2005 & 3 & 3 & 89,7 & 47,05 & 47,24 \\
\hline Malawi & 2004.3 & 4 & 4 & 90,51 & 51,88 & 39,02 \\
\hline Malezja & 2004 & 5 & 4 & 7,88 & 1,39 & 37,91 \\
\hline Mali & 2006 & 2 & 2 & 77,22 & 36,61 & 38,99 \\
\hline Meksyk & 2006 & 2 & 2 & 4,83 & 0,97 & 48,11 \\
\hline Moldova Rep. & 2004 & 3 & 4 & 29,12 & 7,94 & 35,6 \\
\hline Mongolia & 2005 & 2 & 2 & 49,24 & 17,32 & 33,03 \\
\hline Morocco & 2007 & 5 & 4 & 14,08 & 3,18 & 40,88 \\
\hline Nepal & 2003.5 & 5 & 4 & 77,67 & 37,93 & 47,3 \\
\hline Nikaragua & 2005 & 3 & 3 & 31,97 & 12,31 & 52,33 \\
\hline Niger & 2005 & 3 & 3 & 85,66 & 46,76 & 52,33 \\
\hline Nigeria & 2003.7 & 4 & 4 & 84 & 46,99 & 42,93 \\
\hline Pakistan & 2004.5 & 6 & 5 & 60,53 & 18,86 & 31,18 \\
\hline Panama & 2006 & 1 & 2 & 17,91 & 7,09 & 54,93 \\
\hline Paragwaj & 2005 & 3 & 3 & 18,46 & 7,36 & 53,89 \\
\hline Peru & 2005 & 2 & 3 & 19,49 & 6,3 & 51,97 \\
\hline Filipiny & 2006 & 3 & 3 & 45,18 & 16,43 & 44,04 \\
\hline Polska & 2005 & 1 & 1 & 0,57 & 0,12 & 34,92 \\
\hline Rumunia & 2005 & 3 & 2 & 3,44 & 0,87 & 31,5 \\
\hline Rosja & 2005 & 6 & 5 & 1,51 & 0,26 & 37,51 \\
\hline Senegal & 2005 & 2 & 3 & 60,52 & 24,76 & 39,19 \\
\hline Sierra Leone & 2003 & 4 & 4 & 76,19 & 37,64 & 42,52 \\
\hline Słowenia & 2004 & 1 & 1 & 0 & 0 & 31,15 \\
\hline
\end{tabular}


Tabela 1. Wskaźniki wolności i ubóstwa (ciąg dalszy)

\begin{tabular}{|c|c|c|c|c|c|c|}
\hline & ROK ANKIETY & $\begin{array}{l}\text { WoLNOŚĆ } \\
\text { POLITYCZNA }\end{array}$ & $\begin{array}{c}\text { WoLNOŚĆ́ } \\
\text { SWOBÓD } \\
\text { OBYWATELSKICH }\end{array}$ & $\begin{array}{c}\text { ZASIĘG } \\
\text { UBÓSTWA (\%) }\end{array}$ & $\begin{array}{c}\text { GŁĘBOKOŚĆ } \\
\text { UBÓSTWA (\%) }\end{array}$ & $\begin{array}{c}\text { WSKAŻNIK } \\
\text { GINIEGO }\end{array}$ \\
\hline Tadżykistan & 2004 & 6 & 5 & 51,08 & 16,86 & 33,61 \\
\hline Tajlandia & 2004 & 2 & 3 & 11,63 & 1,98 & 42,45 \\
\hline Togo & 2006 & 6 & 5 & 69,48 & 28,03 & 34,41 \\
\hline Turcja & 2005 & 3 & 3 & 9,11 & 2,66 & 43,23 \\
\hline Uganda & 2005 & 5 & 4 & 75,72 & 36,48 & 42,62 \\
\hline Ukraina & 2005 & 4 & 3 & 0,49 & 0,12 & 28,21 \\
\hline Urugwaj urban & 2005 & 1 & 1 & 4,51 & 0,7 & 44,94 \\
\hline Uzbekistan & 2003 & 7 & 6 & 76,82 & 33,3 & 36,72 \\
\hline Wenezuela & 2005 & 3 & 4 & 19,9 & 8,41 & 47,61 \\
\hline Wietnam & 2006 & 7 & 5 & 48,59 & 16,29 & 37,77 \\
\hline Jemen & 2005 & 5 & 5 & 46,79 & 14,85 & 37,69 \\
\hline Zambia & 2004.3 & 4 & 4 & 81,6 & 48,36 & 50,74 \\
\hline
\end{tabular}

Źródło: opracowanie własne na podstawie raportów Freedom House oraz Banku Światowego.

$\mathrm{Na}$ wykresie pierwszym przedstawiono poszczególne państwa ujęte w badaniu, uwzględniając zależność stopy ubóstwa od wolności. Oś odciętych reprezentuje sumę wolności politycznej i wolności swobód obywatelskich dla każdego kraju. Oznacza to, że maksymalny poziom wolności na wykresie wynosi $2(1+1)$, minimalny zaś $14(7+7)$. Oś rzędnych z kolei reprezentuje stopę ubóstwa (\%).

Należy zaznaczyć, że na wykresie nie zamieszczono krajów wysoko rozwiniętych, takich jak np. Niemcy, Norwegia, Holandia, Stany Zjednoczone oraz wiele innych ${ }^{27}$, ponieważ uniemożliwiłoby to czytelność wykresu 1 . Kraje te charakteryzują się bowiem maksymalnym poziomem wolności (na wykresie 1 będzie to wielkość 2) oraz niskim, niewiele różniącym się od siebie poziomem ubóstwa.

Rosnący trend na wykresie 1 wskazuje na ujemną zależność korelacyjną. W miarę zmniejszania się rozmiarów wolności (w kierunku liczby 14) rośnie odsetek gospodarstw ubogich. Wykres nie daje jednak jednoznacznej odpowiedzi na pytanie o stopień i kierunek zależności między wolnością a zasięgiem ubóstwa. Nie powinno dziwić, że wiele najbardziej rozwiniętych krajów, niezaznaczonych na wykresie, charakteryzuje się maksymalnym poziomem wolności i niską stopą ubóstwa, jak np. Polska, która została zaznaczona na wykresie 1 jako jeden $\mathrm{z}$ reprezentantów krajów wysoko rozwiniętych o maksymalnym poziomie wolności oraz niskiej stopie ubóstwa . Istnieją jednak kraje, które odznaczają się brakiem

${ }^{27}$ Por. http://www.freedomhouse.org. 
wolności przy relatywnie niskim poziomie ubóstwa (np. Azerbejdżan), oraz kraje wolne przy bardzo wysokim procentowo udziale ubogiej populacji (np. Mali).

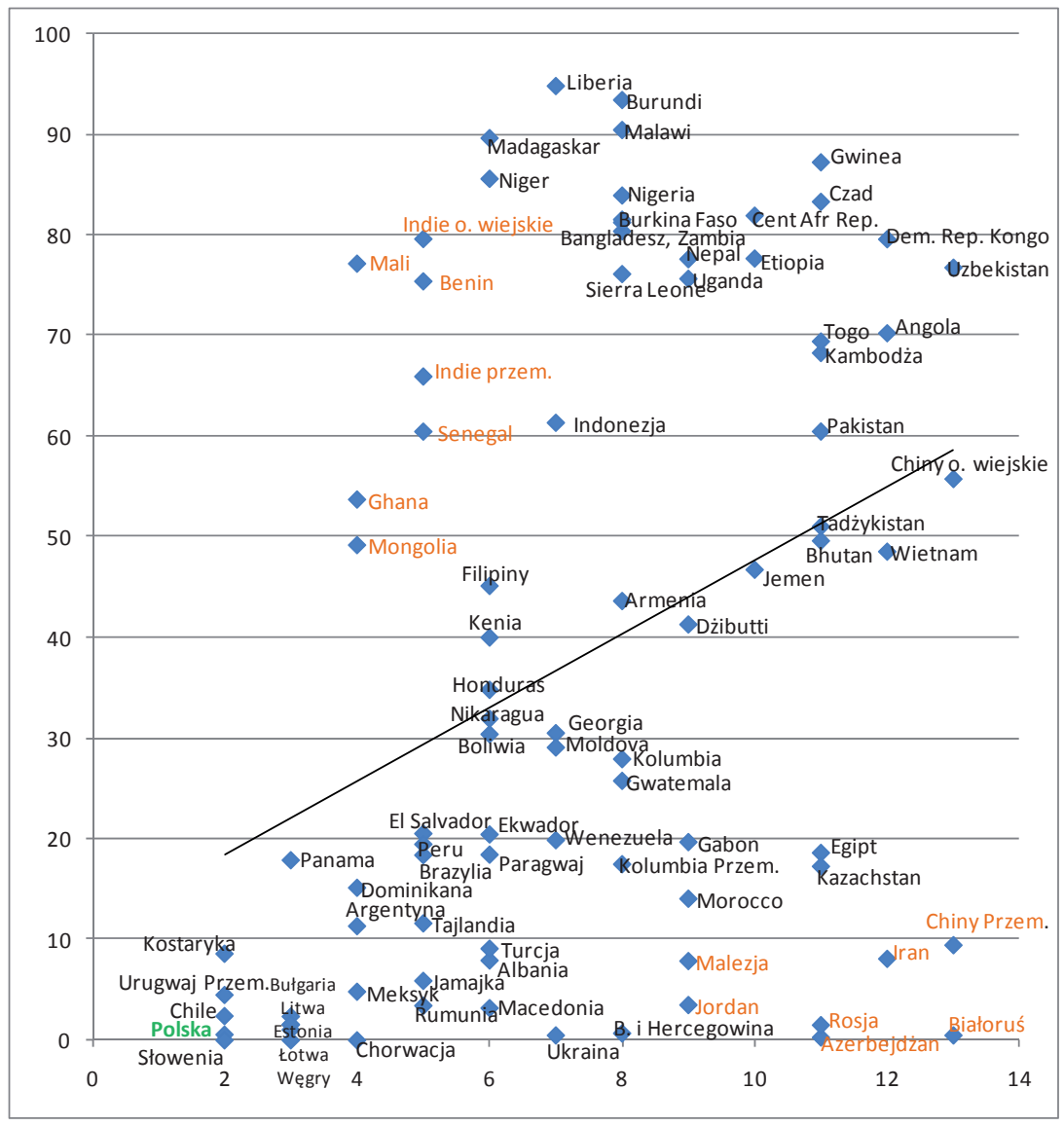

Wykres 1. Zależność stopy ubóstwa (Y) mierzonej parytetem siły nabywczej za 2005 rok* od poziomu wolności (X) dla wybranych krajów w roku 2005

Symbol * oznacza rok tak jak w ankiecie w tabeli 1 dla niektórych państw.

Źródło: opracowanie własne na podstawie raportów Freedom House i Banku Światowego.

Niejednoznaczne wnioski przedstawiają także wykres 2, opisujący zależność głębokości ubóstwa od wolności, oraz wykres 3, opisujący zależność współczynnika Giniego od wolności.

Wykres 2 sugeruje wzrost głębokości ubóstwa w miarę zrzekania się wolności, chociaż jego wyniki nie są jednoznaczne. Istnieją bowiem państwa o niskim poziomie głębokości ubóstwa i o braku wolności gospodarczej oraz państwa częściowo wolne o wysokiej wartości luki dochodowej. 


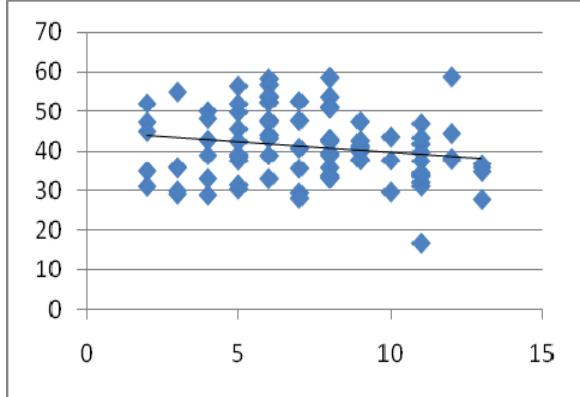

Wykres 2. Zależność wolności i głębokości ubóstwa, rok 2005*

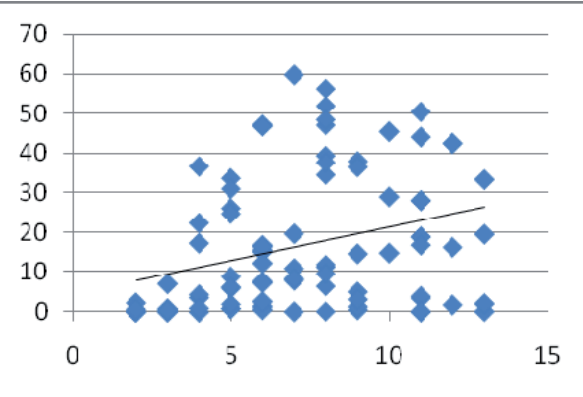

Wykres 3. Zależność wolności i indeksu Giniego, rok 2005*

Symbol * oznacza rok tak jak w ankiecie w tabeli 1 dla niektórych państw. Źródło: opracowanie własne na podstawie raportów Freedom House i Banku Światowego.

Wykres 3 charakteryzuje się trendem spadkowym. W miarę wzrostu wolności rośnie zróżnicowanie dochodów. Wynik ten nie powinien być zaskoczeniem. Nierówności dochodowe i majątkowe to element demokracji i wolnego rynku. Problem nierówności jest coraz częściej poruszany w rozwiniętych krajach świata, gdzie na przestrzeni lat nierówności stają się coraz większe.

Wyjaśnieniem fenomenu krajów o niskim poziomie wolności przy niskiej stopie ubóstwa i głębokości ubóstwa jest prawdopodobnie ustrój niedemokratyczny. Wszystkie bowiem kraje spełniające ten warunek za wyjątkiem Rosji (od lat 1993/1994), takie jak Chiny (przemysłowa część), Białoruś, Iran, Azerbejdżan, Malezja oraz Jordanie są krajami o ustroju niedemokratycznym nawet obecnie, tj. w 2009 roku (por. wykres 1) ${ }^{28}$. Brak demokracji w tych krajach może być przyczyną niskiej stopy oraz głębokości ubóstwa. Zatem to nie brak wolności jest prawdopodobną przyczyną niewielkich rozmiarów ubóstwa, tylko charakterystyczne uwarunkowania instytucjonalne i ustrojowe. Istnieją także kraje zaliczone do grupy krajów wolnych (te, dla których suma wolności politycznych i wolności swobód obywatelskich nie przekracza 5), które odznaczają się bardzo wysoką stopą ubóstwa i jego głębokości. Zaliczają się do nich: Mongolia, Ghana, Mali, Senegal, Indie oraz Benin. Senegal oraz Indie są to kraje, które uzyskały status wolnych stosunkowo niedawno. Senegal jest państwem wolnym dopiero od 2003 roku, Ghana od 2000 roku, natomiast Indie od 1998 roku (czyli do momentu ankiety - 2005 rok - minęło zaledwie 7 lat). Zmiany ustrojowe, ujawnienie się ukrytego bezrobocia mogą stanowić przyczynę ubóstwa na wysoką skalę. Skala ta zależna jest też od stopnia zdeformowania gospodarki przez poprzednie ustroje. Pozostałe kraje są demokracjami od dłuższego czasu. Mongolia oraz Benin są 
uznawane za kraje wolne już od 1991 roku, natomiast Mali od 1995 roku. Pozostałe kraje uwzględnione w badaniu zachowują się z pewnymi odchyleniami zgodnie z zasadą, że mniej wolności oznacza większą stopę i głębokość ubóstwa (por. wykresy 1 i 2). Większa wolność niesie ze sobą niestety większe prawdopodobieństwo wyższych nierówności społecznych (por. wykres 3).

\section{ZAKOŃCZENIE}

Niniejszy artykuł pokazał, że wolność nie jest w stanie zapewnić pokonania problemu ubóstwa, że sama w sobie nie jest warunkiem wystarczającym ${ }^{29}$. Istnieje bowiem wiele krajów o relatywnie wysokiej wolności oraz stopie ubóstwa przekraczającej 50\%. Niektóre kraje stanowią przykład, że wolność nie jest czasem nawet warunkiem koniecznym do zmniejszenia stopy ubóstwa. Dotyczy to zwłaszcza krajów o niedemokratycznym ustroju, gdzie prawdopodobnie polityka proredystrybucyjna lub polityka gwarantowania zatrudnienia powoduje zmniejszenie rozmiarów stopy ubóstwa. Wniosek, jaki z tego płynie, jest następujący: wolność, żeby spełniała swoje funkcje, musi utrzymywać się przez pewien czas oraz dodatkowo muszą istnieć odpowiednie instytucje, muszą być ustanowione odpowiednie warunki, tak aby przyczyniała się do ogólnospołecznego dobrobytu. Samo zagwarantowanie wolności - nawet bardzo wysokiej w krajach, które zostały zniszczone przez wojny lub przewroty systemowe - nie rozwiązuje, przynajmniej w okresie kilkuletnim, problemu ubóstwa. Należy jednak zwrócić uwagę, że wszystkie kraje wysoko rozwinięte charakteryzują się zarówno maksymalnym poziomem wolności politycznej, jak i swobód obywatelskich przy relatywnie niskiej stopie ubóstwa. Ostatecznie zatem wyłania się pozytywna korelacja między większą wolnością a stopą ubóstwa. Wyjątkami są kraje, które cieszą się wolnością stosunkowo niedługo, oraz kraje o ustrojach niedemokratycznych. Mimo znacznych odchyleń i wyjątków można zatem sformułować wniosek o pozytywnym wpływie wolności na stopę ubóstwa. Porównanie z kolei zależności wolności z głębokością ubóstwa oraz jego społecznym rozkładem pozwala na wyciągnięcie wstępnych wniosków, że im większa wolność, tym mniejsza głębokość ubóstwa, ale niestety tym większe rozwarstwienie dochodów w społeczeństwie.

${ }^{29}$ R. A. Sarico, How will freedom succeed?, Delivered April 24, 2008, Heritage Foundation: http://www.heritage.org/Research/Thought/hl1090.cfm. 


\section{THE INFLUENCE OF THE LEVEL OF FREEDOM ON THE DEGREE OF MARKET FAILURES IN SELECTED COUNTRIES - THE PROBLEM OF POVERTY \\ SUMMARY}

The article presents that freedom itself cannot solve the problem of poverty. It turns out that freedom is not a sufficient condition. Some countries are a good example that sometimes freedom is not even a necessary condition. Freedom itself is not enough to assure high standards of living and it is not enough to avoid market failures. In order to make freedom useful, there is needed time and appropriate institutions, appropriate conditions, the context of the environment. Although, there are some deviations and exceptions, the general outcome of the analyses carried out in this article is that the higher freedom we have, the lower the poverty line and poverty gap are. Unfortunately more freedom also means more income inequality. 
